\title{
TINGKAT PENGETAHUAN MASYARAKAT SEKITAR OBSERVATORIUM MENGENAI INFORMASI POLUSI CAHAYA
}

\author{
Laila Nurfarida $^{1}$, Pawit M. Yusup ${ }^{2}$, Neneng Komariah ${ }^{3}$ \\ 1,2,3 Program Studi Ilmu Perpustakaan Universitas Padjadjaran \\ ${ }^{1}$ laila12002@mail.unpad.ac.id, ${ }^{2}$ pawitmy@gmail.com, ${ }^{3}$ nenengkomariah@yahoo.com
}

\begin{abstract}
This research is aimed to know the knowledge level of the society around Bosscha Observatory in Lembang about light pollution. The research was conducted using a survey method to 98 respondents in Lembang Village, Lembang District, West Bandung District. Based on the results of the research, it is revealed that the knowledge level of the society around Bosscha Observatory Lembang about light pollution is categorized as high. It is based on the research on four dimensions of knowledge with high results for factual, conceptual, and procedural knowledge, thus indicating that the public knows well the term, indicators, causes, disorder, harmful nature, the countermeasure solution, the countermeasure techniques, and the criteria of when to apply the procedure of light pollution countermeasure. Then, the next is medium results for metacognition knowledge indicating that the public knows enough information resources, the importance of countermeasures, and the awareness of the knowledge about light pollution. Therefore the society is expected to be wiser in using artificial light and contribute to reducing light pollution.
\end{abstract}

Keywords: Knowledge, Light Pollution, Bosscha Observatory.

ABSTRAK - Penelitian ini bertujuan untuk
mengetahui tingkat pengetahuan masyarakat
sekitar Observatorium Bosscha Lembang mengenai
polusi cahaya. Penelitian dilakukan dengan metode
survei terhadap 98 responden di Desa Lembang,
Kecamatan Lembang, Kabupaten Bandung Barat.
Berdasarkan hasil penelitian diketahui bahwa
tingkat pengetahuan masyarakat sekitar
Observatorium Bosscha Lembang mengenai polusi
cahaya termasuk kedalam kategori tinggi. Hal
tersebut didasarkan pada penelitian terhadap
empat dimensi pengetahuan dengan hasil tinggi
untuk pengetahuan faktual, konseptual, dan
prosedural sehingga mengindikasikan bahwa
masyarakat mengetahui dengan baik mengenai
istilah, indikator, penyebab, gangguan, sifat
merugikan, solusi penanggulangan, teknik
penanggulangan, dan kriteria kapan

mengaplikasikan prosedur penanggulangan polusi cahaya. Kemudian hasil sedang untuk pengetahuan metakognisi sehingga mengindikasikan bahwa masyarakat cukup mengetahui sumber informasi, pentingnya upaya penanggulangan, dan kesadaran terhadap pengetahuan polusi cahaya. Dengan begitu diharapkan masyarakat dapat lebih bijak dalam penggunaan pencahayaan dan berkontribusi nyata dalam upaya mereduksi polusi cahaya.

Kata Kunci: Informasi, Pengetahuan, Polusi Cahaya.

\section{PENDAHULUAN}

Dewasa ini, permasalahan mengenai kelestarian lingkungan hidup harus menjadi tanggung jawab bersama. Pasalnya, semakin hari kualitas lingkungan hidup di sekitar kita semakin menurun. Penurunan kualitas lingkungan hidup dapat dilihat dari tercemarnya sumber daya alam yang ada.

Salah satu bentuk pencemaran lingkungan yang masih kurang mendapat perhatian adalah pencemaran yang disebabkan oleh polusi cahaya. Observatorium Bosscha menyebutkan dalam sebuah artikel Informasi Polusi Cahaya bahwa polusi cahaya merujuk pada keadaan cahaya yang berlebih baik cahaya yang berasal dari sumber-sumber alamiah maupun dari sumber-sumber buatan yang menimbulkan rasa ketidaknyamanan (Bosscha, n.d.).

Dalam kondisi normal, polusi cahaya banyak ditimbulkan oleh sumber-sumber cahaya buatan. 
Sumber-sumber cahaya buatan diantaranya adalah lampu penerangan jalan, lampu-lampu reklame, lampu dekorasi, lampu taman, lampu dari stadion olahraga, dan lampu penerangan luar lainnya. Polusi cahaya berbeda dari konsep pencemaran polusi yang lain. Polusi cahaya tidak berarti cahaya yang mendapat efek pencemaran, tetapi cahaya itu sendiri yang menjadi polutan bagi kondisi gelapnya langit malam.

Salah satu dampak negatif dari polusi cahaya adalah terganggunya proses pengamatan astronomi. Hal ini dikarenakan kondisi langit yang cerah menyebabkan benda-benda langit menjadi sulit untuk diamati. Permasalahan ini dirasakan sendiri oleh salah satu observatorium terbesar dan tertua di Indonesia yakni Observatorium Bosscha yang terletak di kabupaten Bandung Jawa Barat. National Geographic Indonesia (Indonesia, 2015) menyebutkan idealnya, pengamatan benda langit dilakukan dalam kondisi gelap atau setara dengan skor magnitudo 22 seperti saat Observatorium Bosscha berdiri. Sekarang ini nilai kegelapan itu turun menjadi 18 magnitudo. Artinya, langit di sekitar Observatorium Bosscha 40 kali lebih terang dibandingkan ketika Bosscha baru berdiri.

Kondisi tersebut dirasakan sangat mengganggu dan sudah dalam kondisi yang mendesak sehingga Lembaga Penerbangan dan Antariksa Nasional (Lapan) dalam website resminya menyatakan akan membangun Observatorium Nasional di Kupang, NTT. Informasi ini diperkuat oleh pernyataan kepala Lapan yakni Thomas Djamaluddin "di Bandung, dari segi polusi cahaya sudah sangat parah. Teman-teman dari ITB melakukan survei ke berbagai lokasi di Indonesia, yang akhirnya pilihan jatuh ke sebuah wilayah di NTT," ujar Thomas usai penandatanganan nota kesepahaman (MoU) dengan Provinsi NTT dan Kabupaten Kupang di kantor Lapan, Rawamangun, Jakarta Timur, Rabu, 7 Oktober 2015 (Nasional, 2015)

Sebenarnya Permasalahan polusi cahaya memiliki kesempatan lebih mudah untuk diselesaikan. Seperti yang dikatakan Duriscoe (Adelheid, 2011) tidak seperti isu lingkungan seperti pemanasan global atau asap perkotaan, masalah polusi cahaya mudah diselesaikan, bahkan di daerah metropolitan besar. Penggunaan cahaya buatan secara tepat mampu menurunkan tingkat polusi cahaya yang ada. Pihak observatorium Bosscha secara aktif melakukan berbagai upaya untuk menurunkan tingkat polusi cahaya di sekitar observatorium. Salah satunya upaya penyelamatan Bosscha dengan gerakan membagikan tudung lampu secara gratis kepada masyarakat sekitar radius 200-300 meter dari Observatorium Bosscha. Pembagian tudung lampu pertama kali dilakukan pada bulan februari 2015 sebanyak 300 buah. Dengan menggunakan tudung lampu, cahaya lampu tidak akan terhambur ke arah langit sehingga mampu mencegah terjadinya polusi cahaya. Pihak Bosscha sadar dengan langkah kecil ini tidak akan langsung menyelamatkan Bosscha dari polusi cahaya. Namun, gerakan ini akan terus dilakukan dengan harapan langkah ini mampu membuat pemerintah tergerak untuk mengoptimalkan langkah penyelamatan Bosscha (Indonesia, 2015).

Untuk mengoptimalkan upaya penyelamatan Observatorium dari polusi cahaya diperlukan kerjasama dari masyarakat khususnya masyarakat di sekitar Observatorium itu sendiri. Hal ini 
dikarenakan pertambahan jumlah penduduk di sekitar Observatorium berperan aktif menambah tingkat polusi cahaya yang terjadi di langit Observatorium. Hal tersebut menjadi permasalahan tersendiri karena hingga saat ini belum dapat dipastikan jika masyarakat mengetahui informasi polusi cahaya yang terjadi disekitarnya.

Maka dari itu, penulis tergerak melakukan penelitian untuk mengetahui sejauh mana tingkat pengetahuan masyarakat sekitar Observatorium mengenai informasi polusi cahaya. Penelitian ini didasari oleh rasa tanggung jawab penulis sebagai seseorang yang memiliki latar belakang keilmuan informasi dan perpustakaan terhadap isu lingkungan yang terjadi di masyarakat. Dimana salah satu fungsi perpustakaan adalah informasi yang menurut Purwono fungsi informasi, dalam hal tertentu berfungsi sebagai tempat lahirnya informasi (Purwono, 2013).

Adapun rumusan masalah dalam penelitian ini dititikberatkan pada "Seberapa tinggi tingkat pengetahuan masyarakat sekitar Observatorium mengenai informasi polusi cahaya”. Aspek pengetahuan dalam hal ini dibatasi dengan empat poin utama. Pertama, pengetahuan faktual yang mencakup pengetahuan mengenai istilah dan indikator polusi cahaya. Kedua, pengetahuan konseptual yang mencakup kategori, prinsip, dan teori polusi cahaya. Ketiga, pengetahuan prosedural yang mencakup keterampilan yang berhubungan dengan polusi cahaya, teknik penanggulangan, dan kriteria kapan mengaplikasikan prosedur penanggulangan polusi cahaya. Keempat, pengetahuan metakognisi yang mencakup sumber informasi, pentingnya upaya penanggulangan dan kesadaran kepemilikan pengetahuan polusi cahaya. Sehingga tujuan dari penelitian ini adalah untuk mengetahui seberapa tinggi tingkat pengetahuan faktual, konseptual, prosedural dan metakognisi masyarakat sekitar Observatorium mengenai informasi polusi cahaya.

\section{TINJAUAN PUSTAKA}

Pengetahuan merupakan hasil tahu yang didapatkan dari hasil penginderaan terhadap suatu objek (Wawan \& Dewi, 2010). Pengetahuan termasuk kedalam ranah kognitif yang berkaitan dengan kemampuan dalam aspek intelektual seperti keterampilan dalam berpikir dan mengungkapkan kembali objek pengetahuan yang telah diketahui.

Menurut Kratwohl terdapat empat unsur yang membentuk dimensi pengetahuan yakni pengetahuan faktual, konseptual, prosedural dan metakognisi (Krathwohl, 2002). Pengetahuan faktual merupakan unsur dasar yang harus diketahui untuk mengenal dan memecahkan masalah pada objek pengetahuan. Pengetahuan faktual terdiri dari dua komponen yakni pengetahuan terhadap aspek terminologi dan pengetahuan terhadap rincian spesifik dan elemen objek pengetahuan. Pengetahuan konseptual merupakan pengetahuan mengenai hubungan antar unsur-unsur dasar objek pengetahuan dalam skala yang lebih besar dan mendukung satu sama lain. Pengetahuan konseptual terdiri dari tiga komponen yakni pengetahuan mengenai klasifikasi dan kategori, pengetahuan mengenai prinsip dan generalisasi, dan pengetahuan mengenai teori, model, dan struktur. Pengetahuan prosedural, merupakan pengetahuan mengenai bagaimana 
melakukan sesuatu, metode penyelidikan, kriteria untuk menggunakan keterampilan, alogaritma, teknik, dan metode. Pengetahuan prosedural terdiri dari tiga komponen yakni pengetahuan keterampilan subjek khusus dan algoritma, pengetahuan tentang teknik subjek khusus dan metode, pengetahuan tentang kriteria untuk menentukan kapan menggunakan prosedur yang tepat. Pengetahuan prosedural, merupakan pengetahuan mengenai bagaimana melakukan sesuatu, metode penyelidikan, kriteria untuk menggunakan keterampilan, alogaritma, teknik, dan metode. Pengetahuan prosedural terdiri dari tiga komponen yakni pengetahuan keterampilan subjek khusus dan algoritma, pengetahuan tentang teknik subjek khusus dan metode, pengetahuan tentang kriteria untuk menentukan kapan menggunakan prosedur yang tepat. Pengetahuan metakognitif, merupakan pengetahuan tentang kognisi serta kesadaran secara umum dan pengetahuan seseorang mengenai kognisinya sendiri. Pengetahuan metakognitif terdiri dari tiga komponen yakni pengetahuan strategis, pengetahuan tentang tugas kognitif termasuk kontekstual dan kondisional, dan pengetahuan mengenai kemampuan kognitif diri sendiri.

Pengetahuan yang dimiliki seseorang akan dipengaruhi oleh faktor internal (pendidikan, pekerjaan, umur) dan faktor eksternal (lingkungan, sosial budaya) (Wawan \& Dewi, 2010). Hal tersebut menyebabkan tingkat pengetahuan seseorang akan berbeda satu sama lain tergantung konsdisi dan situasi dari faktor yang menstimulasi orang tersebut. Begitupun halnya dengan pengetahuan masyarakat mengenai polusi cahaya.
Polusi cahaya merupakan konsekuensi yang tidak diinginkan dari pencahayaan luar ruangan yang menimbulkan efek seperti terangnya langit malam, cahaya pada tempat yang tidak diinginkan, dan silau (Renssealer Polytechnic Institute, 2007). Polusi cahaya sendiri merupakan pencemaran yang memerlukan penanganan sesegera mungkin untuk mengurangi dampak negatif yang ditimbulkannya. Maka dari itu pengetahuan masyarakat mengenai polusi cahaya sangat diperlukan sebagai langkah awal dari upaya penyelamatan langit malam dari polusi cahaya.

\section{METODE PENELITIAN}

Penelitian ini merupakan penelitian kuantitatif dengan metode survei deskriptif. Metode survei deskriptif dinilai sebagai metode yang paling sesuai dengan penelitian ini berdasarkan kepada beberapa pertimbangan yaitu: (1) penelitian ini hanya bertujuan mendeskripsikan objek penelitian tanpa menguji hipotesis dan tanpa melihat hubungannya dengan aspek lain sebagaimana yang diungkapkan Purwanto bahwa penelitian deskriptif hanya melibatkan satu variabel pada satu kelompok, tanpa menghubungkan dengan variabel lain atau membandingkannya dengan kelompok lain (Purwanto, 2012) (2) luasnya populasi penelitian, dan (3) jumlah populasi yang relatif banyak sehingga memerlukan pengambilan sampel penelitian.

Penelitian ini dilakukan di sekitar Observatorium Bosscha yang terletak di Desa Lembang, Kecamatan Lembang, Kabupaten Bandung Barat. Lokasi ini ditentukan berdasarkan pertimbangan bahwa Observatorium Bosscha merupakan Observatorium terbesar serta tertua di 
Indonesia dan Observatorium Bosscha sendiri mengalami permasalahan yang disebabkan oleh gangguan polusi cahaya dari sekitarnya.

Populasi dalam penelitian ini adalah masyarakat sekitar Observatorium Bosscha Lembang yang terdiri dari 4000 KK (kepala keluarga) dengan karakteristik perwakilan dari satu KK (kepala keluarga), laki-laki atau perempuan, dan Berada satu wilayah dengan Observatorium Bosscha dengan batasan pemerintahan Desa.

Kemudian jumlah sampel yang diperlukan sebagai perwakilan dari keseluruhan populasi diketahui sejumlah 98 orang dengan perhitungan menggunakan rumus Slovin berikut:

$$
\begin{aligned}
& \mathbf{n}=\frac{N}{N d^{2}+1} \\
& \mathrm{n}=\frac{4000}{4000(0.1)^{2}+1} \\
& \mathrm{n}=\frac{4000}{4000(0.1)^{2}+1} \\
& \mathrm{n}=97,56 \\
& \mathrm{n}=\text { dibulatkan menjadi } 98
\end{aligned}
$$

keterangan :

$\mathrm{n}$ : jumlah sampel yang dicari

$N$ : jumlah populasi

$d$ : nilai presisi (ditentukan dalam penelitian ini sebesar $90 \%$ atau $=0,1$ )

Teknik pegambilan sampel yang digunakan adalah metode sampling area. Sampling area merupakan metode pengambilan sampel dengan mengkategorikan suatu area yang luas kedalam beberapa bagian yang lebih kecil sehingga lebih mudah untuk diteliti. Sehubungan populasi dalam penelitian ini merupakan populasi area yang dibatasi dengan batas geografis desa, maka penulis membagi populasi area Desa Lembang dalam batasan RW (Rukun Warga) yang terdiri dari 16 RW. Untuk menentukan pembagian jumlah sampel dari masing-masing RW, penulis menggunakan rumus hitung pengambilan sampel secara proporsional atau imbangan dengan hasil sebagai berikut:

Tabel 1

Keadaan populasi dan sampel penelitian

\begin{tabular}{|c|c|c|c|}
\hline No. & RW & Populasi & Sampel \\
\hline 1 & 01 & 251 & 6 \\
\hline 2 & 02 & 288 & 7 \\
\hline 3 & 03 & 271 & 6 \\
\hline 4 & 04 & 284 & 7 \\
\hline 5 & 05 & 199 & 5 \\
\hline 6 & 06 & 379 & 9 \\
\hline 7 & 07 & 288 & 7 \\
\hline 8 & 08 & 427 & 10 \\
\hline 9 & 09 & 103 & 3 \\
\hline 10 & 10 & 114 & 3 \\
\hline 11 & 11 & 281 & 7 \\
\hline 12 & 12 & 233 & 6 \\
\hline 13 & 13 & 353 & 9 \\
\hline 14 & 14 & 141 & 3 \\
\hline 15 & 15 & 200 & 5 \\
\hline 16 & 16 & 188 & 5 \\
\hline Jumlah & $\mathbf{4 0 0 0}$ & $\mathbf{9 8}$ \\
\hline
\end{tabular}

Sumber : hasil pengolahan data 2016

\section{PEMBAHASAN}

Pengetahuan

masyarakat

sekitar

Observatorium Bosscha Lembang mengenai polusi cahaya diukur dengan menggunakan angket sebagai sumber data utama yang disebar pada bulan Mei 2016. Berdasarkan sumber data penelitian, berikut hasil penelitian yang telah penulis dapatkan.

Berdasarkan analisis data responden dengan menggunakan teknik distribusi frekuensi, diketahui bahwa karakteristik responden didominasi oleh jenis kelamin laki-laki sebanyak 
$60.2 \%$. Kemudian untuk usia responden didominasi oleh rentang usia 18-35 tahun sebanyak $40.8 \%$. Untuk status pendidikan terakhir didominasi oleh lulusan SMA/sederajat sebanyak $54.1 \%$. Dan untuk pekerjaan responden didominasi oleh Ibu Rumah Tangga sebanyak $34.7 \%$, pekerjaan ini mendominasi karena pekerjaan untuk responden dengan jenis kelamin laki-laki terbagi kedalam banyak kategori pekerjaan lainnya.

Untuk mengetahui tingkat pengetahuan faktual, konseptual, prosedural dan metakognisi masyarakat sekitar Observatorium Bosscha Lembang mengenai polusi cahaya digunakan metode analisis distribusi frekuensi dengan tiga kategori yakni kategori rendah, sedang, dan tinggi. Hasil penelitian diketahui sebagai berikut:

Tabel 2

Hasil Penelitian

\begin{tabular}{|l|c|c|c|}
\hline $\begin{array}{c}\text { Sub } \\
\text { Variabel }\end{array}$ & Kategori & $\begin{array}{c}\text { Frekuensi } \\
\text { (f) }\end{array}$ & $\begin{array}{c}\text { Persentase } \\
(\%)\end{array}$ \\
\hline Faktual & Tinggi & 78 & 79.6 \\
\hline Konseptual & Tinggi & 79 & 80.6 \\
\hline Prosedural & Tinggi & 82 & 83.7 \\
\hline Metakognisi & Sedang & 41 & 41.8 \\
\hline
\end{tabular}

Sumber : Hasil Penelitian 2016

Sub variabel pengetahuan faktual mendapatkan hasil kategori tinggi dengan persentase $79.6 \%$ yang mengindikasikan bahwa masyarakat mengetahui dengan baik berbagai indikator terkait pengetahuan faktual mengenai polusi cahaya. Indikator pertama dari pengetahuan faktual adalah pengetahuan mengenai definisi polusi cahaya dan fakta penting bahwa polusi cahaya merupakan keadaan dimana cahaya menjadi sumber polusi (polutan) bukan menjadi objek polutan. Indikator kedua adalah pengetahuan mengenai indikator polusi cahaya yakni penggunaan cahaya lampu yang tidak tepat sasaran, penggunaan cahaya lampu berlebih, dan kumpulan cahaya buatan yang menyilaukan.

Sub variabel pengetahuan konseptual mendapatkan kategori tinggi dengan persentase 80.6\% yang mengindikasikan bahwa masyarakat mengetahui dengan baik berbagai indikator terkait pengetahuan konseptual mengenai polusi cahaya. Indikator pertama adalah pengetahuan mengenai kategori sumber polusi cahaya yang terdiri dari penggunaan lampu secara berlebihan dan kumpulan cahaya lampu dari pemukiman. Kemudian indikator kedua adalah prinsip polusi cahaya bahwa polusi cahaya mengganggu pengamatan di Observatorium dan mengganggu kesehatan. American Medical Association Council on Science and Public Health (2012) (dalam International Dark Sky Association, 2014) menyatakan bahwa efek samping silau dari pencahayaan pada malam hari dapat membahayakan mulai dari kondisi tidak nyaman sampai menyebabkan disabilitas (cacat). Indikator ketiga adalah teori polusi cahaya yang menyatakan bahwa polusi cahaya bersifat merugikan. Sifat merugikan polusi cahaya dapat dilihat dari berbagai dampak negatifnya yang tidak bisa dianggap sebelah mata begitu saja. Jika suatu saat nanti kita hanya bisa melihat bintang dari buku atau televisi karena langit terhalang oleh hamparan cahaya maka merugi lah kita, seperti yang diungkapkan Amazon

"If we are led to assume that the Earth is all that exists, and that stars and planets belong in picture books, on cinema and TV screens and computer monitors, because they cannot be 
seen in skies invaded by wasted upward light, we fall into an ultimate and dangerous vanity" (Association, 2009).

Sub variabel pengetahuan prosedural mendapatkan hasil kategori tinggi dengan persentase $83.7 \%$ yang mengindikasikan bahwa masyarakat mengetahui dengan baik berbagai indikator terkait pengetahuan prosedural mengenai polusi cahaya. Indikator pertama adalah keterampilan yang berhubungan dengan polusi cahaya yang berisi pengetahuan mengenai solusi penanggulangan polusi cahaya. Indikator kedua adalah pengetahuan mengenai teknik penanggulangan polusi cahaya dengan menggunakan tudung lampu, mengarahkan lampu ke tempat yang diperlukan, dan penggunaan lampu hemat energi. Berikut derajat sudut arah pemasangan lampu yang disarankan:

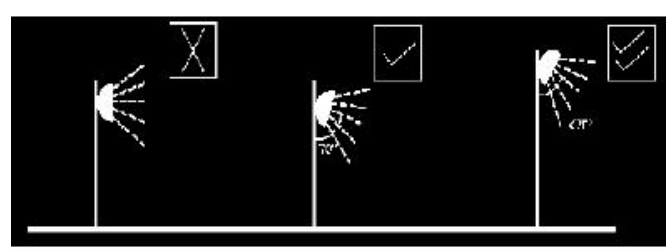

Gambar 1

\section{Sudut Arah Lampu yang Benar}

Sumber : (Trespass, 2000)

Indikator ketiga adalah pengetahuan mengenai kriteria kapan mengaplikasikan prosedur penanggulangan polusi cahaya dengan pengaturan waktu penggunaan cahaya lampu.

Sub variabel pengetahuan metakognisi mendapatkan hasil kategori sedang dengan persentase $41.8 \%$ yang mengindikasikan bahwa masyarakat cukup mengetahui berbagai indikator terkait pengetahuan metakognisi mengenai polusi cahaya. Indikator pertama adalah pengetahuan mengenai strategi untuk mendapatkan sumber informasi mengenai polusi cahaya apakah melalui tetangga, media massa, atau lembaga tertentu. Berdasarkan hasil survei di lapangan sumber informasi yang banyak digunakan oleh masyarakat adalah media massa sebanyak $63.3 \%$ dengan media televisi dan koran, kemudian informasi dari lembaga tertentu dengan persentase $57.1 \%$ yang berasal dari sekolah dan Observatorium Bosscha. Indikator kedua adalah tugas kognisi dari polusi cahaya berupa pengetahuan mengenai pentingnya upaya mengurangi polusi cahaya. Untuk poin ini hampir semua reponden mengetahui pentingnya upaya mengurangi polusi cahaya yakni sebanyak 94.9\%. Kemudian indikator ketiga adalah kesadaran masyarakat terhadap pengetahuan polusi cahaya, apakah masyarakat menyadari atau tidak bahwa mereka memiliki pengetahuan tentang polusi cahya. Untuk poin ini masyarakat sebanyak 81.6\% menyadari bahwa mereka memiliki pengetahuan tentang polusi cahaya.

Untuk menambahkan informasi terkait penelitian ini, penulis menambahkan analisis data dengan teknik tabulasi silang antara umur, pendidikan terakhir, dan pekerjaan responden dengan tingkat pengetahuan mengenai polusi cahaya. Berdasarkan hasil analisis ini diketahui bahwa jumlah terbanyak hasil tabulasi silang untuk umur dengan tingkat pengetahuan adalah pada rentang usia 36-53 tahun dengan kategori pengetahuan tinggi. Kemudian untuk tabulasi silang antara pendidikan terakhir dengan tingkat pengetahuan didominasi oleh lulusan SMA/sederajat dengan kategori pengetahuan tinggi. Lalu tabulasi silang antara pekerjaan dengan tingkat pengetahuan didominasi oleh 
karyawan swasta dengan kategori pengetahuan tinggi.

\section{SIMPULAN}

Tingkat pengetahuan faktual masyarakat sekitar Observatorium mengenai informasi polusi cahaya termasuk kedalam kategori tinggi. Hasil tersebut mengindikasikan bahwa masyarakat mengetahui dengan baik istilah dan indikator dari polusi cahaya.

Tingkat pengetahuan konseptual masyarakat sekitar Observatorium mengenai informasi polusi cahaya termasuk kedalam kategori tinggi. Hasil tersebut mengindikasikan bahwa masyarakat mengetahui dengan baik mengenai penyebab polusi cahaya, gangguan yang disebabkan oleh polusi cahaya, dan sifat merugikan dari polusi cahaya.

Tingkat pengetahuan prosedural masyarakat sekitar Observatorium mengenai informasi polusi cahaya termasuk kedalam kategori tinggi. Hasil tersebut mengindikasikan bahwa masyarakat mengetahui dengan baik mengenai solusi penanggulangan polusi cahaya, teknik penanggulangan polusi cahaya, dan kriteria kapan mengaplikasikan prosedur penanggulangan polusi cahaya.

Tingkat pengetahuan metakognisi masyarakat sekitar Observatorium mengenai informasi Polusi cahaya termasuk kedalam kategori sedang. Hasil tersebut mengindikasikan bahwa masyarakat cukup mengetahui mengenai sumber informasi polusi cahaya, pentingnya upaya penanggulangan polusi cahaya, dan kesadaran bahwa masyarakat memiliki pengetahuan mengenai polusi cahaya.

\section{DAFTAR PUSTAKA}

Adelheid, F. (2011). Starry Night. Retrieved from https://placesjournal.org/article/starry-night/

Association, B. A. (2009). Campaign for Dark Skies (CfDS): Blinded by the Light? Retrieved from http://www.britastro.org/dark-skies/pdfs/HA NDBOOKTEXT.pdf

Bosscha, O. (n.d.). Informasi Polusi Cahaya. Retrieved January 27, 2016, from http://bosscha.itb.ac.id/en/informasi-polusi-c ahaya-layanan-61.html

Indonesia, N. G. (2015). Tudung Lampu Ini Akan Menyelamatkan Observatorium Bosscha. Retrieved January 27, 2016, from http://nationalgeographic.co.id/berita/2015/0 3/tudung-lampu-ini-akan-menyelematkan-ob servatorium-bosscha

International Dark Sky Association. (2014). Human Health. Retrieved June 9, 2016, from http://darksky.org/light-pollution/human-heal th/

Krathwohl, D. R. (2002). A Revision of Bloom's Taxonomy: An Overview. Theory Into Practice, $\quad$ 41(4), 212-218. https://doi.org/10.1207/s15430421tip4104_2 Nasional, L. (Lembaga P. dan A. (2015). Polusi Cahaya, Bosscha tak Layak Lagi. Retrieved June $\quad 19, \quad 2016, \quad$ from http://www.lapan.go.id/index.php/subblog/re $\mathrm{ad} / 2015 / 1997 / / 2112$

Purwanto. (2012). Metode Penelitian Kuantitatif: Untuk Psikologi dan Pendidikan. Yogyakarta: Pustaka Pelajar.

Purwono. (2013). Profesi Pustakawan Menghadapi Tantangan Perubahan. 
Yogyakarta: Graha Ilmu.

Renssealer Polytechnic Institute. (2007). What is Light Pollution? National Lighting Product Information Program, 7(2). Retrieved from http://www.lrc.rpi.edu/programs/nlpip/lightin ganswers/lightpollution/lightpollution.asp

Trespass, L. (2000). The Institution of Lighting
Engineers guidance notes for the reduction of light pollution. Development, 44(227499), 3-6.

Wawan, \& Dewi. (2010). Teori dan Pengukuran Pengetahuan, Sikap, dan Perilaku Manusia: Dilengkapi Contoh Kuesioner. Yogyakarta: Yuha Medika. 
